\title{
A CORRUPÇÃO COMO FATOR IMPEDITIVO DA DEMOCRACIA: UMA LEITURA DA OBRA GLÓRIA INCERTA APLICADA AO BRASIL
}

\author{
CORRUPTION AS A DISINCENTIVE OF DEMOCRACY: ONE READING ABOUT \\ THE BOOK UNCERTAIN GLORY APPLIED TO BRAZIL
}

\section{Adamir André Silva ${ }^{1}$}

SUMÁRIO: Introdução; 1 Corrupção; 2 Democracia; 3 Problemas de Corrupção; Considerações Finais, Referências Bibliográficas.

\section{RESUMO}

Este artigo tem por objetivo analisar o tema inerente ao problema da corrupção como fator impeditivo da democracia. A corrupção condena a sociedade ao subdesenvolvimento ao gerar a desigualdade. A corrupção é a negação das promessas Constitucionais e, uma barreira à efetivação dos direitos fundamentais. Nesta seara, o problema versa sobre: Em que medida a corrupção e/ou aumento da corrupção torna-se um fator impeditivo para a democracia ou para um Estado Democrático de Direito. Percebe-se que as causas que elevam este índice minimizam a efetivação da democracia; a corrupção está inserida nas instituições políticas e sociais, todavia, é necessária uma mudança de valores culturais e cívicos capaz de potencializar um Estado Democrático, pois a dinâmica do poder corrói e inibe a conquista e efetivação da democracia. O locus de análise se dá a partir da obra: Glória Incerta: A Índia e suas contradições, uma vez que essa traz a análise de diversos fatores que impedem a efetivação da Democracia naquele Estado, e entre estes, a corrupção impacta negativamente. Ainda pretendeu-se estabelecer um ponto de contato entre a realidade da Índia e do Brasil, que enfrenta o mesmo problema, sofrendo as mesmas consequências, e aparentemente pode ter a solução com a adoção de medidas semelhantes. Adotou-se como método de abordagem o dedutivo, e como método de procedimento a pesquisa bibliográfica, uma vez que é a mais se adapta ao campo jurídico.

\footnotetext{
${ }_{1}^{1}$ Mestrando em Direito da Faculdade Meridional (IMED-RS), Passo Fundo, Linha de Pesquisa - Fundamentos do Direito e da Democracia, Especialista em Ciências Criminais pela Universidade de Passo Fundo (UPF-RS), Procurador do Município de Passo Fundo, Advogado, Endereço Eletrônico: adamirandreadvogado@terra.com.br
} 
SILVA, Adamir André. A corrupção como fator impeditivo da democracia: uma leiturada obra Glória Incerta aplicada ao Brasil. Revista Eletrônica Direito e Política, Programa de PósGraduação Stricto Sensu em Ciência Jurídica da UNIVALI, Itajaí, v.11, n.2, 2ㅇ quadrimestre de 2016. Disponível em: www.univali.br/direitoepolitica - ISSN 1980-7791.

Palavras-chave: Corrupção. Democracia. Sustentabilidade.

\section{ABSTRACT}

This article aims to analyze the topic inherent to the problem of corruption as an impediment to democracy. Corruption condemns society to underdevelopment by producing inequality. Corruption is denying Constitutional promises and a barrier to the effectiveness of fundamental rights. In this scope, the problem lies in which level corruption and/or the increase in corruption becomes an impediment to democracy or to a Democratic State. It is observed that causes increasing this rate minimize the effectiveness of democracy. Corruption is inserted in political and social institutions, however, a change of cultural and civic values that can enhance a Democratic State is required, considering that power dynamics corrodes and inhibits conquering the effectiveness of democracy. The analysis locus is obtained from the work "Glória Incerta: A Índia e suas contradições" (Uncertain Glory: India and its contradictions), which analyzes several impediments to the effectiveness of democracy in that State, and among them, corruption presents a negative impact. It was also intended to establish a contact point between the realities of India and Brazil, which is facing the same problem, suffering the same consequences, and it apparently may have the solution such as adopting similar measures. The approach method adopted was deductive, and the procedure method was bibliographic research, for being mostly used in the legal field.

Keywords: Corruption. Democracy. Sustainability.

\section{INTRODUÇÃO}

Este artigo tem por proposição analisar o tema inerente ao problema da corrupção como fator impeditivo da democracia na leitura de Amartya Sen e Jean Drèze na obra: Glória Incerta: A Índia e suas contradições, estabelecendo pontos comuns da realidade indiana e brasileira, sobretudo porque aparentam ter as mesmas causas, consequências, e podem adotar programas semelhantes para a solução.

A corrupção corrói a dignidade do cidadão, contaminando o indivíduo em seu convívio social, afetando o poder público, por consequência torna-se uma das causas da pobreza e da inacessibilidade à serviços essências, 
SILVA, Adamir André. A corrupção como fator impeditivo da democracia: uma leiturada obra Glória Incerta aplicada ao Brasil. Revista Eletrônica Direito e Política, Programa de PósGraduação Stricto Sensu em Ciência Jurídica da UNIVALI, Itajaí, v.11, n.2, 20 quadrimestre de 2016. Disponível em: www.univali.br/direitoepolitica - ISSN 1980-7791.

mitigando o princípio da igualdade e da liberdade devido ao desvio de recursos públicos. A corrupção condena a sociedade ao subdesenvolvimento ao gerar a desigualdade.

Nesta esteira, visa-se abordar a corrupção, sob o prisma do direito, considerando-a um impedimento à democracia contemporânea de Glória Incerta, numa releitura ambientada à realidade brasileira.

O obra tratou de aspectos essenciais do estado indiano, no que se refere à Democracia e os fatores que impedem a sua efetivação. Dentre as causas que impedem essa concretização pode-se destacar: a existência de arraigada corrupção em todos os setores da sociedade; desigualdade entre classes; e a mídia controlada pelo poder econômico. Diante dessa constatação analisa-se o porquê da não efetivação da prometida glória, ou sucesso daquela sociedade, dai denominar-se Glória Incerta e com base nessa premissa, traçar um paralelo com o Estado brasileiro, que também clama por medidas que, combatendo a corrupção, efetive a democracia.

Portanto, a pesquisa busca analisar o problema da corrupção como fator impeditivo da democracia, mediante a observação do aumento dos índices de corrupção, pois acaba por lesar a sociedade e o Estado. Dessa forma, o problema versa sobre: Em que medida a corrupção e/ou aumento da corrupção é um fator impeditivo da democracia ou de um Estado Democrático de Direito, na releitura da obra Glória Incerta a Índia e suas contradições aplicada à realidade indiana e brasileira?

A relevância do tema centra-se no sentido, que os efeitos da corrupção são identificados na escassez de verbas, para manutenção e implementação de políticas públicas sociais, pois os recursos são drenados comprometendo a economia, por consequência todas as necessidades da sociedade vinculadas ao bem estar e ao desenvolvimento social. 

Glória Incerta aplicada ao Brasil. Revista Eletrônica Direito e Política, Programa de PósGraduação Stricto Sensu em Ciência Jurídica da UNIVALI, Itajaí, v.11, n.2, 20 quadrimestre de 2016. Disponível em: www.univali.br/direitoepolitica - ISSN 1980-7791.

Há que se abordar a corrupção não só em termos civis e criminais, mas também eticamente, para que não seja criada uma cultura de regra, de normalidade, e, sim, de exceção. Segundo Bobbio² "[...] para uma definição mínima de democracia, $[. .$.$] , é preciso que aqueles que são$ chamados a decidir ou a eleger os que deverão decidir sejam colocados diante de alternativas reais e postos em condição de poder escolher [...]". Ou seja, para o autor existe na democracia o direito de liberdade, em relação à opinião, de expressar ideias, trata-se do "[...] reconhecimento constitucional dos direitos "invioláveis" do indivíduo". A conquista da democracia gerou o reconhecimento de inúmeros direitos ao indivíduo, os quais quando negligenciados comprometem o fortalecimento democrático.

Para tratar do tema proposto adota-se como método de abordagem o dedutivo, e como método de procedimento a pesquisa bibliográfica, uma vez que é a mais se adapta ao campo jurídico.

Assim, propõe-se uma reflexão acerca dos limites e das possibilidades do Direito e da Democracia. E, por fim, não há como analisar democracia e sustentabilidade, sem admitir, pelo menos em tese, que há um problema que causa uma fissura no Estado Democrático de Direito, que é a corrupção.

\section{CORRUPÇÃo}

Antes de adentrar nas questões inerentes a corrupção, é preciso inferir que a sociedade precisa exigir, bem como comprometer-se com a ética e com a transparência em todas as esferas, sejam institucionais, econômicas, sociais, públicas ou privadas.

BOBBIO, Norberto. O futuro da democracia: uma defesa das regras do jogo. Tradução de Marco Aurélio Nogueira. Rio de Janeiro: Paz e Terra, 1986. p. 20. 
SILVA, Adamir André. A corrupção como fator impeditivo da democracia: uma leiturada obra Glória Incerta aplicada ao Brasil. Revista Eletrônica Direito e Política, Programa de PósGraduação Stricto Sensu em Ciência Jurídica da UNIVALI, Itajaí, v.11, n.2, 2ㅇ quadrimestre de 2016. Disponível em: www.univali.br/direitoepolitica - ISSN 1980-7791.

Não se encontra facilmente uma definição jurídica de corrupção, a doutrina estrangeira posiciona-se: "E aqui nos deparamos com primeiro desafio, no direito alemão não há uma conceituação jurídica para corrupção, tampouco existe no uso corrente da língua uma definição bem precisa, única e universalmente aceita." 3

O que se encontra rotineiramente é a definição dos crimes que correspondem a corrupção, ou seja, os diversos tipos penais que compõem a prática da corrupção.

Porém com o intuito de oferecer uma descrição, o autor aconselha, para o entendimento do fenômeno, adotar a definição de Joseph S. Nye:

\begin{abstract}
"Nye define o sentido de corrupção como o comportamento de um detentor de cargo público que, movido por interesses particulares ou pra ter alguma vantagem pecuniária ou ganho de status, adota uma conduta que constitui um desvio das obrigações do seu cargo ou viola as regras vigentes da sua função para exercer alguma influência como pessoa privada. Resumindo: a corrupção deve ser entendida como "abuso do poder inerente a um cargo (público) que lhe foi confiado, visando a obter benefícios pessoais."
\end{abstract}

Nota-se claramente o desvio da conduta do agente, o proveito próprio, e também calha salientar que é um conceito já firmado a algumas décadas na doutrina estadunidense.

Importante ainda grifar, que não existem sociedades livres da corrupção. O senso comum, crê que países como Alemanha, Itália, Espanha estão totalmente imunes, o que não é verdadeiro. As formas que se manifestam as práticas corruptivas dizem respeito a atividade política, sobretudo no que se refere ao financiamento de campanhas políticas e o aumento

3 AVRITZER, Leonardo; FILGUEIRAS, Fernando. Corrupção e sistema político no Brasil. Rio de Janeiro: Civilização Brasileira, 2011.p. 224.

${ }^{4}$ AVRITZER, Corrupção e sistema político no Brasil. 2011, p. 224. 
SILVA, Adamir André. A corrupção como fator impeditivo da democracia: uma leiturada obra Glória Incerta aplicada ao Brasil. Revista Eletrônica Direito e Política, Programa de PósGraduação Stricto Sensu em Ciência Jurídica da UNIVALI, Itajaí, v.11, n.2, 2ㅇ quadrimestre de 2016. Disponível em: www.univali.br/direitoepolitica - ISSN 1980-7791.

constante do custo dessas campanhas. Na Alemanha, uma das formas de controle é a transparência das contas públicas.

Um meio de evitar a prática da corrupção se inicia com a adoção de medidas que possibilitem o acompanhamento dos gastos públicos. A transparência das contas públicas, através de mecanismos eficientes de controle, e a implementação de uma gestão responsável, cria um ambiente desfavorável a desvios:

A questão da accountability está estreitamente relacionada com a
da corrupção, que recebeu uma grande atenção em debates
políticos recentes na Índia. Na ausência de bons sistemas de
accountability, além de graves negligências de deveres, pode
haver muita tentação para os funcionários públicos de taxar a
"preços" elevados o que eles na verdade deveriam entregar como
parte de seu trabalho. Essa "recompensa", um exemplo de
corrupção com base em privilégio oficial, também pode causar
uma distorção de um serviço supostamente público em benefício
de pessoas que têm os meios e a vontade de comprar favores. A
corrupção tornou-se uma característica endêmica da administração
e vida comercial indianas que, em algumas partes do país, nada se
move na direção pretendida a menos que a mão do servidor seja
molhada.

Neste sentido accountability, dá a noção de um acompanhamento, controle dos agentes públicos responsáveis pela prestação de contas e ainda, com um monitoramento permanente das atividades exercidas.

No excerto colacionado, está presente a definição de corrupção sustentada pelos autores: o receber algo - corrupção passiva, e o comprar favores corrupção ativa, todavia a descrição é feita mais como comportamento do sujeito, que conceitualmente.

\footnotetext{
${ }^{5}$ DRĖZE, Jean; SEN, Amartya. Glória Incerta: A Índia e suas contradições. Tradução de Ricardo Doninelli Mentes e Laila Coutinho. São Paulo: Companhia das Letras, 2015. p.113.
}

${ }^{6}$ DRÈZE; SEN, Glória Incerta: A Índia e suas contradições. 2015, p.113. 
SILVA, Adamir André. A corrupção como fator impeditivo da democracia: uma leiturada obra Glória Incerta aplicada ao Brasil. Revista Eletrônica Direito e Política, Programa de PósGraduação Stricto Sensu em Ciência Jurídica da UNIVALI, Itajaí, v.11, n.2, 2ㅇ quadrimestre de 2016. Disponível em: www.univali.br/direitoepolitica - ISSN 1980-7791.

Percebe-se aí a forma de distorção do poder do agente público, exigindo algo em benefício próprio, forma mais elementar de corrupção.

Adiante, há referência à fragilização da Democracia pela prática imoral: "...No entanto, a democracia exige não só que as queixas sobre essas terríveis práticas sejam extensamente divulgadas, mas também que isso leve a uma séria discussão sobre o que pode ser feito de forma racional para resolver o problema." 6

O termo accountability, se expandiu e têm aplicação efetiva também na doutrina brasileira, aparecendo como a boa prática de fiscalização da gestão pública., indicando, desde logo, também aqui, uma das formas de combate à corrupção.

Existe um lugar comum na gestão pública contemporânea: o
reconhecimento do princípio da transparência das ações do Estado
na sociedade, caracterizado por um amplo consenso entre
políticos, burocratas e formadores de opinião de que não devem
existir segredos na relação entre Estado e sociedade. Tal ideia cria
uma enorme expectativa de que a transparência serviria à maior
articulação e organização da administração pública, além de
contribuir para a concretização da accountability e, por
consequência, para a diminuição da corrupção. ${ }^{7}$

A prática da corrupção, tem suas raízes firmadas no tripé: lacunas de informação, leniência social e dificuldade acusatória.

Pelo menos três diferentes questões são centrais para prevalência da corrupção nos serviços públicos. Primeiro, a corrupção floresce em um contexto de obscuridade informacional: por natureza, é uma atividade secreta. Uma mudança institucional que promova a transparência e o acesso à informação pode ser uma força atuante contra a prevalência da corrupção e do peculato. Em segundo lugar, a corrupção sobrevive em um ambiente de tolerância, não importando como as pessoas "morais" tendam a ver tais delitos. Uma crença geral de que a corrupção é o "comportamento padrão"

7 AVRITZER, Leonardo; FILGUEIRAS, Fernando. Corrupção e sistema político no Brasil. Rio de Janeiro: Civilização Brasileira, 2011. p. 133. 
SILVA, Adamir André. A corrupção como fator impeditivo da democracia: uma leiturada obra Glória Incerta aplicada ao Brasil. Revista Eletrônica Direito e Política, Programa de PósGraduação Stricto Sensu em Ciência Jurídica da UNIVALI, Itajaí, v.11, n.2, 2o quadrimestre de 2016. Disponível em: www.univali.br/direitoepolitica - ISSN 1980-7791.

e tem de ser tolerada, a não ser que os desvios sejam totalmente expostos e flagrantes, pode gerar uma situação em que os caçadores de propina não sofram muita pressão para corrigir-se, seja por parte de seus pares, seja por parte de sua própria consciência. Em terceiro lugar, a corrupção pode ser reduzida através de uma ameaça real de acusação e sanção. ${ }^{8}$

Diante de tal afirmação podemos perceber alguns pilares onde se apoia a corrupção. Evidentemente que existem outros fatores que levam a prática dessa moléstia que assola a sociedade, todavia resumiram os fatores externos que determinam no indivíduo a opção pela prática corrupta.

Há uma preferência ao privado, o benefício próprio em detrimento do bem comum. Revela o egoísmo do indivíduo, uma preocupação somente com seu bem-estar: "Nesta metateoria da corrupção, é possível identificar a seguinte constante lógica: a corrupção é a sobreposição das vantagens privadas sobre o bem comum, significando um ato de decoro para com a ética." ${ }^{\prime 9}$

Segue ainda o autor, com fundamento em Aristóteles e Políbios, demonstrando a preferência ao privado, nos seguintes termos:

Com o inventário das noções de Aristóteles e Políbios sobre a política e a forma segundo a qual é possível compreender este fenômeno prático, podemos identificar a constante lógica que define a corrupção enquanto antinomia da organização justa dos homens em coletividade. A corrupção na política é a sobreposição das vantagens privadas sobre o bem comum. Sua causa está no baixo alcance da ética, expressa, como observa Políbios, tanto nas leis quanto que nos costumes. De outro lado, uma primeira consequência que podemos identificar é seu caráter destruidor comunidade política. Uma comunidade em que seus participantes

${ }^{8}$ DRĖZE, Jean; SEN, Amartya. Glória Incerta: A Índia e suas contradições. Tradução de Ricardo Doninelli Mentes e Laila Coutinho. São Paulo: Companhia das Letras, 2015. p. 114-115.

9 AVRITZER, Leonardo; FILGUEIRAS, Fernando. Corrupção e sistema político no Brasil. Rio de Janeiro: Civilização Brasileira, 2011. p.133. 
SILVA, Adamir André. A corrupção como fator impeditivo da democracia: uma leiturada obra Glória Incerta aplicada ao Brasil. Revista Eletrônica Direito e Política, Programa de PósGraduação Stricto Sensu em Ciência Jurídica da UNIVALI, Itajaí, v.11, n.2, 2o quadrimestre de 2016. Disponível em: www.univali.br/direitoepolitica - ISSN 1980-7791.

apenas busquem vantagens privadas e não consigam formular uma ideia de bem comum - eudamonia - faz com que todos percam, porque a finalidade da organização coletiva não resulta na felicidade, apesar de ser um fenômeno necessário para que alcancemos o entendimento do que seja a eudamonia. ${ }^{10}$

Certo é que a Índia vive um regime democrático, o que alias é reconhecida como a maior democracia do mundo, todavia com problemas dessa natureza, ocorre a fragilização da Democracia e soluções têm que ser implantadas, porque o que se busca é o bem comum.

Tanto quanto no Brasil, estão presentes na Índia questões relacionadas a educação, cuidados básicos na saúde, instalação de um sistema de serviços públicos eficaz e responsável. Soluções que deveriam ser sanadas pela realização da promessa política contida na democracia, e que ainda aguardam para serem eficazmente implantadas.

Com isso se faz necessário a aproximação de uma definição de Democracia.

\begin{abstract}
A democracia envolve, como já assinalei, uma relação política entre cidadãos no interior da estrutura básica da sociedade na qual nasceram e na qual normalmente passam toda a sua vida; isso implica ainda uma parte igual no poder político coercitivo que os cidadãos exercem uns sobre os outros ao votar, e de outras formas também. Enquanto razoáveis e racionais, e sabendo-se que endossam uma grande diversidade de doutrinas religiosas e filosóficas razoáveis, os cidadãos devem estar dispostos a explicar a base de suas ações uns para os outros em termos que cada qual razoavelmente espere que outros possam aceitar, por serem coerentes com a liberdade e igualdade dos cidadãos. Procurar satisfazer essa condição é uma das tarefas que esse ideal de política democrática exige de nós. Entender como se comportar enquanto cidadão democrático inclui entender um ideal de razão pública. ${ }^{11}$
\end{abstract}

${ }^{10}$ AVRITZER, Corrupção e sistema político no Brasil. 2011, p. 10.

11 RAWLS, John. O liberalismo político. Tradução Dinah de Abreu Azevedo. Editor Fenando Paixão. São Paulo, 1993. p. 266-267. 
SILVA, Adamir André. A corrupção como fator impeditivo da democracia: uma leiturada obra Glória Incerta aplicada ao Brasil. Revista Eletrônica Direito e Política, Programa de PósGraduação Stricto Sensu em Ciência Jurídica da UNIVALI, Itajaí, v.11, n.2, 2ㅇ quadrimestre de 2016. Disponível em: www.univali.br/direitoepolitica - ISSN 1980-7791.

Diante do elemento novo denominado Razão Pública, há a seguinte explanação:

A introdução do adjetivo 'pública' além da característica de uma razão geral e destinada a um conjunto da sociedade, tem como objetivo assinalar o bem de todos, isto é, o bem comum. Nesse quesito é fundamental salvaguardar as garantias de igualdade, liberdade e acesso às posições destacadas nos princípios da justiça. A razão pública está sintetizada nos princípios por terem a missão de orientar o funcionamento de uma sociedade, especialmente as instituições e o moral dos seus membros. ${ }^{12}$

No que se refere ao Brasil, percebe-se que está vivenciando o maior período de democratização de sua história, todavia ainda é recente, como explicam Santos e Amanajás, "essa jovem democracia ainda possui vários obstáculos para se consolidar"13, dentre eles a corrupção. Nesta seara, mencionam os autores:

\begin{abstract}
Um dos princípios do Direito Penal Brasileiro é o de que tudo que a lei não proíbe é permitido. Seguindo este raciocínio, as oligarquias e o clientelismo político nada mais são do que formas legalizadas de corrupção, institucionalizadas na democracia brasileira, de tal maneira que passa a ser corriqueira e despercebida a sua prática. $\mathrm{Na}$ verdade, é uma forma de tirania indireta em que o governante apesar de não estar ferindo a legislação pátria diretamente, vai de encontro a todos os princípios democráticos e éticos, que devem reger, acima de tudo, a relação entre governo e governados. ${ }^{14}$
\end{abstract}

Constata-se que, inúmeros estudos têm abordado o tema corrupção e seus efeitos, dentre estes, à Ciência Política, Filosofia, História, Direito, Sociologia, os quais demonstram que a corrupção possui efeitos

12 ZAMBAN, Neuro José. Introdução à Teoria da Justiça de John Rawls. Rio de Janeiro: Lumen Juris, 2016. p. 150-151.

13 SANTOS, Kátia P.; AMANAJÁS, Alley Felipe. Democracia e corrupção no Brasil: a face tirana do poder político. Estação Científica (UNIFAP), Macapá, v. 2, n. 1, p. 11-24, jan./jun., 2012. p.12.

${ }^{14}$ SANTOS, Kátia P.; AMANAJÁS, Alley Felipe. Democracia e corrupção no Brasil: a face tirana do poder político. Estação Científica (UNIFAP), Macapá, v. 2, n. 1, p. 11-24, jan./jun., 2012. p.16. 
SILVA, Adamir André. A corrupção como fator impeditivo da democracia: uma leiturada obra Glória Incerta aplicada ao Brasil. Revista Eletrônica Direito e Política, Programa de PósGraduação Stricto Sensu em Ciência Jurídica da UNIVALI, Itajaí, v.11, n.2, 2ㅇ quadrimestre de 2016. Disponível em: www.univali.br/direitoepolitica - ISSN 1980-7791.

negativos, corroendo os alicerces do sistema político e, aumentando a desconfiança da sociedade sobre as instituições. ${ }^{15}$

Do ponto de vista conceitual a corrupção sempre foi analisada
como um problema limitado à ação das autoridades políticas, ou
seja, políticos eleitos e burocratas do Estado, e como um problema
econômico, tendo em consideração a lógica dos custos e dos
benefícios da corrupção para o desenvolvimento e para a
modernização. O conceito de corrupção, nessa perspectiva, parte
da ideia de que a sua prática representa uma ação intencional por
parte de uma autoridade, a qual tende a sobrepor seus interesses
privados ao interesse comum, tendo em vista uma estrutura
normativa pouco institucionalizada, a qual determina as fronteiras
de uma ação ou não aceita no interior do sistema $\left[\ldots . . .{ }^{16}\right.$

Nesta esteira, a própria sociedade, mesmo no seu senso comum, conceitua a corrupção, como uma prática imoral, seja em âmbito público ou privado, pois esta contraria normas fundamentais de interesse público.

Entretanto, percebe-se que, atualmente a corrupção está fortemente associada ao cenário político e econômico do País, por atingir toda a sociedade, constata-se que há a apropriação do público por interesses privados.

Tocqueville sustenta:

A intriga e a corrupção constituem vícios naturais dos governos eletivos. Mas quando o chefe do Estado pode ser reeleito, esses vícios se estendem indefinidamente e comprometem a própria existência do país. Se um simples candidato quisesse vencer pela

15 MORAES, Thiago Perez Bernardes de; SANTOS, Romer Mottinha; TORRECILLAS, Geraldo Leopoldo da Silva. Qualidade democrática, percepção de corrupção e confiança política na América Latina. Revista Eletrônica de Ciência Política, v. 5, n. 1, 2014. p. 16.

16 MORAES, Thiago Perez Bernardes de; SANTOS, Romer Mottinha; TORRECILLAS, Geraldo Leopoldo da Silva. Qualidade democrática, percepção de corrupção e confiança política na América Latina. Revista Eletrônica de Ciência Política, v. 5, n. 1, 2014. p.16. 
SILVA, Adamir André. A corrupção como fator impeditivo da democracia: uma leiturada obra Glória Incerta aplicada ao Brasil. Revista Eletrônica Direito e Política, Programa de PósGraduação Stricto Sensu em Ciência Jurídica da UNIVALI, Itajaí, v.11, n.2, 2ㅇ quadrimestre de 2016. Disponível em: www.univali.br/direitoepolitica - ISSN 1980-7791.

intriga, suas manobras só se exerceriam num espaço circunscrito. Se, ao contrário, o próprio chefe de Estado e um dos postulantes, toma emprestada para seu uso próprio a forca do governo. No primeiro caso, e um homem com seus frágeis meios; no segundo, e o próprio Estado, com seus imensos recursos, que intriga e corrompe. ${ }^{17}$

$\mathrm{Na}$ concepção de Leal ${ }^{18}$, é fato que a corrupção atinge direitos fundamentais, pela via dos comportamentos corruptivos de alguns cidadãos, deixando evidente a falha estatal em evitá-los. Neste sentido, exemplifica o autor: "[...] quando alguém paga suborno para obter determinado tratamento médico-hospitalar; ou paga suborno para conseguir vaga escolar, condutas estas que estão a violar os sistemas de ensino e de saúde". Também, indiretamente, "[...] quando autoridades estatais permitem, pela via do suborno, que sejam comercializados resíduos tóxicos e depositados sem as cautelas devidas em áreas de densidade demográfica significativa $[\ldots]^{\prime \prime}$, assim, verifica-se que a

17 TOCQUeVille, A. de. A democracia na América. Tradução: Neil Ribeiro da Silva. São Paulo: Folha de S. Paulo, 2010. p. 118.

18 LEAL, Rogerio Gesta. Os efeitos deletérios da corrupção em face dos direitos humanos e fundamentais. In: LEAL, Rogerio Gesta; SILVA, Ianaiê Simonelli. (Org.). As múltiplas faces da corrupção e seus efeitos na democracia contemporânea [recurso eletrônico]. Santa Cruz do Sul: EDUNISC, 2014. p.11.

BRAUN, Michele. O fenômeno corrupção: de suas raízes a revitalização da cidadania como forma de enfrentamento do vício social. In: LEAL, Rogerio Gesta; SILVA, Ianaiê Simonelli. (Org.). As múltiplas faces da corrupção e seus efeitos na democracia contemporânea [recurso eletrônico]. Santa Cruz do Sul: EDUNISC, 2014.

BRAUN, Michele. O fenômeno corrupção: de suas raízes a revitalização da cidadania como forma de enfrentamento do vício social. In: LEAL, Rogerio Gesta; SILVA, Ianaiê Simonelli. (Org.). As múltiplas faces da corrupção e seus efeitos na democracia contemporânea [recurso eletrônico]. Santa Cruz do Sul: EDUNISC, 2014.

BRAUN, Michele. O fenômeno corrupção: de suas raízes a revitalização da cidadania como forma de enfrentamento do vício social. In: LEAL, Rogerio Gesta; SILVA, Ianaiê Simonelli. (Org.). As múltiplas faces da corrupção e seus efeitos na democracia contemporânea [recurso eletrônico]. Santa Cruz do Sul: EDUNISC, 2014. 
SILVA, Adamir André. A corrupção como fator impeditivo da democracia: uma leiturada obra Glória Incerta aplicada ao Brasil. Revista Eletrônica Direito e Política, Programa de PósGraduação Stricto Sensu em Ciência Jurídica da UNIVALI, Itajaí, v.11, n.2, 2ㅇ quadrimestre de 2016. Disponível em: www.univali.br/direitoepolitica - ISSN 1980-7791.

corrupção abrange inúmeros setores, podendo manifestar-se de diversas formas, e, é a conduta humana que a faz corporificar.

Para Braun:

De fato, a corrupção pode se dar tanto na esfera pública quanto na privada, porém, pode ser visualizada de forma mais nítida quando ocorre na esfera pública. A corrupção nesta esfera desperta de forma mais intensa repulsa da sociedade, que se vê privada de melhores condições de manutenção do Estado por motivo dos desvios de dinheiro público, favores ilegais, benefícios isolados e etc. ${ }^{19}$

Segundo Braun ${ }^{20}$, a corrupção é considerada um dos mais devastadores males da sociedade, trata-se de uma patologia vinculada à natureza humana, que se vê obtendo vantagens e violando o princípio neminem laedere, ou seja, lesando o outro em benefício próprio, mesmo que precise ultrapassar limites éticos, morais e jurídicos. Ao agir por meio da corrupção priva outros ${ }^{21}$ de seus direitos, afrontando direitos fundamentais e comprometendo a democracia.

Fratton comenta:

19 BRAUN, Michele. O fenômeno corrupção: de suas raízes a revitalização da cidadania como forma de enfrentamento do vício social. In: LEAL, Rogerio Gesta; SILVA, Ianaiê Simonelli. (Org.). As múltiplas faces da corrupção e seus efeitos na democracia contemporânea [recurso eletrônico]. Santa Cruz do Sul: EDUNISC, 2014. p. 58.

${ }^{20}$ BRAUN, Michele. O fenômeno corrupção: de suas raízes a revitalização da cidadania como forma de enfrentamento do vício social. In: LEAL, Rogerio Gesta; SILVA, Ianaiê Simonelli. (Org.). As múltiplas faces da corrupção e seus efeitos na democracia contemporânea [recurso eletrônico]. Santa Cruz do Sul: EDUNISC, 2014. p. 58.

${ }^{21}$ A libertação do homem seja ele individual ou social, é questão indissociável da noção de coletividade. Como se vê, para que seja factível vencer um inimigo, é necessário transformar sua humanidade em coisa. Assim, em sentido oposto, a luta pela libertação importa em reconhecer o outro como outro, em sua diferença; mas da identidade da humanidade. Empreender um projeto comum, que ultrapassa os limites da vida do um, que reside na própria coletividade. (GRUBBA, 2011, p. 145). 
SILVA, Adamir André. A corrupção como fator impeditivo da democracia: uma leiturada obra Glória Incerta aplicada ao Brasil. Revista Eletrônica Direito e Política, Programa de PósGraduação Stricto Sensu em Ciência Jurídica da UNIVALI, Itajaí, v.11, n.2, 2ㅇ quadrimestre de 2016. Disponível em: www.univali.br/direitoepolitica - ISSN 1980-7791.

A corrupção, sob o ponto de vista etimológico, provém do latim corruptus, que significa "quebrado em pedaços" e o ato de corromper significa "tornar-se podre", portanto é incontestável que o sentido da palavra corrupção provém da sombra, da desordem, do sujo e da fragmentação que o ato em si provoca. O tema corrupção é complexo face suas múltiplas facetas. De um lado, tem uma conotação púbica pouco fundamentada, opiniões empíricas e sensoriais do que seja corrupção abordadas pelos indivíduos diariamente. Por outro lado, a corrupção, como fenômeno, tem um apelo epistemológico científico muito grande, uma vez que não se trata exclusivamente de um só tipo de conduta de comportamento, assim como também não é causa exclusiva de um tipo de conhecimento, logo, ela advém de um resultado de inúmeras variáveis sob a perspectiva científica do seu significado. ${ }^{22}$

Neste sentido, percebe-se que são inúmeras as abordagens em relação à corrupção, a sociedade brasileira parece ter chegado ao limite, devido aos elevados índices dessa patologia, o que culminou em grandes manifestações e movimentos que dominaram as ruas de todas as cidades do Brasil. Tal fenômeno representa a insatisfação da população com os rumos da inoperância e ineficiência do Estado e dos diversos segmentos da sociedade brasileira. ${ }^{23}$

Para Mazzardo e Costa24 é fato que compete ao Estado, por meio de seus códices posturais e reguladores, primar por ações políticas que venham ao encontro dos interesses da coletividade. Evitando, assim, que os recursos públicos sejam drenados via interesses privados, considerando que

22 FRATTON, Elisangela Furian. A dignidade da pessoa humana e o fenômeno da corrupção no Brasil. In: LEAL, Rogerio Gesta; SILVA, Ianaiê Simonelli. (Orgs.). As múltiplas faces da corrupção e seus efeitos na democracia contemporânea [recurso eletrônico]. Santa Cruz do Sul: EDUNISC, 2014. p. 120.

${ }^{23}$ FRATTON, Elisangela Furian. A dignidade da pessoa humana e o fenômeno da corrupção no Brasil. In: LEAL, Rogerio Gesta; SILVA, Ianaiê Simonelli. (Orgs.). As múltiplas faces da corrupção e seus efeitos na democracia contemporânea [recurso eletrônico]. Santa Cruz do Sul: EDUNISC, 2014, p.125.

24 MAZZARDO, Luciane; COSTA, Marli da. Perscrutando os efeitos da corrupção na realidade pátria: a (des) conexão com os direitos sociais. In: LEAL, Rogerio Gesta; SILVA, Ianaiê Simonelli. (Orgs.). As múltiplas faces da corrupção e seus efeitos na democracia contemporânea [recurso eletrônico]. Santa Cruz do Sul: EDUNISC, 2014. p.198. 
SILVA, Adamir André. A corrupção como fator impeditivo da democracia: uma leiturada obra Glória Incerta aplicada ao Brasil. Revista Eletrônica Direito e Política, Programa de PósGraduação Stricto Sensu em Ciência Jurídica da UNIVALI, Itajaí, v.11, n.2, 20 quadrimestre de 2016. Disponível em: www.univali.br/direitoepolitica - ISSN 1980-7791.

múltiplas são as manifestações do fenômeno corrupção, que acabam por solapar a possibilidade de efetivação dos direitos sociais e fundamentais a uma significativa parcela da população brasileira, que permanece excluída, à margem de tais benefícios.

Dessa forma, observa-se a necessidade de investir em reformas democráticas condizentes e aclamadas pelos movimentos sociais, que visem consolidar a democracia.

\section{DEMOCRACIA}

Importante salientar que no texto paradigma, não ofereceram os autores uma definição de corrupção, oportunizando assim a construção de um conceito de corrupção adaptado à realidade brasileira. Tampouco preocuparam-se com uma definição de Democracia, da mesma forma proporcionando - como conceito universal - a utilização de um conceito de Democracia ambientado a América.

Considerando-se, a igualdade como principal fator da democracia, Alexis de Tocqueville, menciona em sua obra "A democracia na América" que "[...] não é sempre a capacidade que falta à democracia para escolher os homens de mérito, mas o desejo e o gosto". ${ }^{25}$

O filósofo Platão, define a democracia a partir da liberdade, no diálogo entre Sócrates e Adimanto na obra A República, há o seguinte trecho:

Sócrates - E de que maneira esses governam? Como se constitui esse regime? Claro que o cidadão que o acata deve ser chamado democrático.

Adimanto - Sim, é claro.

25 TOCQUeVille, A. de. A democracia na América. Tradução de Neil Ribeiro da Silva. São Paulo: Folha de S. Paulo, 2010. p.155. 
SILVA, Adamir André. A corrupção como fator impeditivo da democracia: uma leiturada obra Glória Incerta aplicada ao Brasil. Revista Eletrônica Direito e Política, Programa de PósGraduação Stricto Sensu em Ciência Jurídica da UNIVALI, Itajaí, v.11, n.2, 20 quadrimestre de 2016. Disponível em: www.univali.br/direitoepolitica - ISSN 1980-7791.

S. - Antes de mais nada, os cidadãos são livres e o Estado respira liberdade e transparência, cada um podendo fazer o que quiser. ${ }^{26}$

Assim, na Grécia antiga, para os filósofos, entre as formas de governo, a democracia é aquela que privilegia a liberdade.

Já Tocqueville, elenca ao menos quatro questões que formam a democracia na América: a igualdade de condições entre os americanos; participação direta dos cidadãos na gestão pública; soberania do povo e das leis - onde o poder emana do povo e, a associação política. Todavia o que Ihe chamou a atenção ao chegar na América, primeiramente, foi o sentimento de igualdade. A igualdade de condições entre os americanos: "Entre os objetos novos, durante a minha demora nos Estados Unidos, atraíram a minha atenção, nenhum me impressionou mais vivamente do que a igualdade de condições."27

Essa fórmula adotada pelos imigrantes ao chegar na América, que é a vontade do povo governando, foi uma característica que chamou a atenção do autor: "Quando se deseja falar das leis políticas dos Estados Unidos, é sempre pelo dogma da soberania do povo que se há de começar."28

Na América, o princípio da soberania popular jamais fica escondido ou estéril, como é em certas nações, é reconhecida pelos costumes, proclamado nas leis, estende-se com toda liberdade e sem obstáculos atinge as suas últimas consequências. Se existe um único país no mundo onde podemos esperar apreciar em seu justo valor o dogma da soberania popular, estudá-lo na sua

26 TOCQueVille, A. de. A democracia na América. Tradução: Neil Ribeiro da Silva. São Paulo: Folha de S. Paulo, 2010, p. 39.

27 TOCQUEVILLE, A democracia na América. 2010, p.39.

28 TOCQUEVILLE, A democracia na América. 2010, p. 71. 
SILVA, Adamir André. A corrupção como fator impeditivo da democracia: uma leiturada obra Glória Incerta aplicada ao Brasil. Revista Eletrônica Direito e Política, Programa de PósGraduação Stricto Sensu em Ciência Jurídica da UNIVALI, Itajaí, v.11, n.2, 2ㅇ quadrimestre de 2016. Disponível em: www.univali.br/direitoepolitica - ISSN 1980-7791.

aplicação aos negócios da sociedade e julgar as suas vantagens e os seus perigos, esse país é, sem dúvida, a América. ${ }^{29}$

Nesse aspecto aproxima-se do pensamento de Hannah Arendt, quanto a esse sentimento de respeito à tradição a lei a forma com que foi concebido o Estado Americano, referindo-se mesmo a um espírito das leis, próprio dos imigrantes americanos:

Teoricamente, este consentimento é interpretado como sendo o resultado de um contrato social, que na sua forma mais comum - o contrato entre o povo e seu governo - é facilmente denunciável como mera ficção. Contudo. A questão é que não era mera ficção na prática pré-revolucionária norte-americana, com seus númerosos pactos e acordos, deste o Pacto de Mayflower, até o estabelecimento das treze colônias como uma entidade quando Locke formulou sua teoria do contrato social, que supostamente explicava a origem aborígene da sociedade civil, ele indicou numa nota lateral que modelo tinha realmente em mente: No princípio o mundo todo era a América. ${ }^{30}$

Privilegia-se também a liberdade, reconhecendo-o já como um elemento constitutivo da Democracia americana.

O compromisso moral do cidadão em obedecer às leis, tradicionalmente provém da suposição de que ele, ou deu seu consentimento a ela, ou foi o próprio legislador, sob o domínio da lei, o homem não está sujeito a uma vontade alheia, está obedecendo a si mesmo - e o resultado, naturalmente, é que cada pessoa é ao mesmo tempo seu próprio senhor e seu próprio escravo. ${ }^{31}$

Essa ligação entre o indivíduo e a norma é porque os próprios cidadãos criaram a lei, e, não obstante tenham cedido parte da liberdade para o Estado que os protegem, a todo momento podem reivindicar esse poder. É o governo do povo e para o povo, que garante inclusive o respeito às minorias.

30 ARENDT, Hannah. Crises da República. Tradução de José Volkmann, São Paulo: Perspectiva, 2015. p.76-77.

${ }^{31}$ ARENDT, Crises da República. 2015. p.76-77. 
SILVA, Adamir André. A corrupção como fator impeditivo da democracia: uma leiturada obra Glória Incerta aplicada ao Brasil. Revista Eletrônica Direito e Política, Programa de PósGraduação Stricto Sensu em Ciência Jurídica da UNIVALI, Itajaí, v.11, n.2, 2ㅇ quadrimestre de 2016. Disponível em: www.univali.br/direitoepolitica - ISSN 1980-7791.

$\mathrm{Na}$ concepção de Habermas ${ }^{32}$, democracia abrange um sistema dos direitos que faça jus à autonomia privada e pública dos cidadãos, deve contemplar os direitos fundamentais que os cidadãos são obrigados a se atribuir mutuamente, caso queiram regular sua convivência com os meios legítimos do direito positivo.

Para Habermas:

[...] O princípio da democracia resulta de uma especificação correspondente para tais normas de ação que surgem na forma do direito e que podem ser justificadas com o auxílio de argumentos pragmáticos, ético-políticos e morais - e não apenas com o auxílio de argumentos morais. Em sociedades complexas, a moral só obtém efetividade em domínios vizinhos, quando é traduzida para o código do direito. [...] o princípio da democracia não se encontra no mesmo nível que o princípio moral. Enquanto este último funciona como regra de argumentação para a decisão racional de questões morais, o princípio da democracia pressupõe preliminarmente a possibilidade da decisão racional de questões práticas, mais precisamente, a possibilidade de todas as fundamentações, a serem realizadas em discursos (e negociações reguladas pelo procedimento), das quais depende a legitimidade das leis. Por si mesmo, o princípio da democracia não é capaz de dizer se e como é possível abordar discursivamente questões políticas $[\ldots] ; i^{33}$

De acordo com Bobbio ${ }^{4}$, existem democracias mais sólidas e menos sólidas, invulneráveis e vulneráveis, em diversos graus aproximam-se do modelo ideal, mas mesmo a democracia mais distante do modelo não pode ser de modo algum confundida com um Estado autocrático e menos ainda com um totalitário. O conceito preliminar de sistema democrático proposto deve ser entendido como um conjunto de regras de

32 HABERMAS, Jürgen. Direito e democracia: entre facticidade e validade. Tradução Flávio Beno Siebeneichler. Rio de Janeiro: Tempo Brasileiro, 2003. p.158.

33 HABERMAS, Direito e democracia: entre facticidade e validade. 2003. p.143-145.

34 BOBBIO, Norberto. O futuro da democracia: uma defesa das regras do jogo. Tradução de Marco Aurélio Nogueira. Rio de Janeiro: Paz e Terra, 1986. p. 50-52. 
SILVA, Adamir André. A corrupção como fator impeditivo da democracia: uma leiturada obra Glória Incerta aplicada ao Brasil. Revista Eletrônica Direito e Política, Programa de PósGraduação Stricto Sensu em Ciência Jurídica da UNIVALI, Itajaí, v.11, n.2, 2ㅇ quadrimestre de 2016. Disponível em: www.univali.br/direitoepolitica - ISSN 1980-7791.

procedimento, sendo que a regra da maioria ${ }^{35}$ é a principal, mas não é a única; o sistema democrático é legitimado na periodicidade de eleições livres e com sufrágio universal; o "grau de democraticidade" de um sistema é determinado pelo posicionamento e pelo deslocamento dos limites incidentes sobre as liberdades, em especial a de associação e a de opinião.

A democracia se vincularia a "uma teoria política que afirme e reconcilie a ideia dos direitos sociais [...]". Isto requer a "intervenção do poder estatal na esfera econômica e cultural, com a ideia não menos justa do poder do individualismo $[\ldots]^{\prime 36}$, já sinalizando os alicerces da democracia dos pensadores liberais.

A democracia e o Estado não podem ir, segundo ele, contra as
massas, senão com as mesmas. Cabe-lhes educá-las, mediante a
politização de seus elementos. [...] O constitucionalismo
democrático emancipou politicamente as massas com o sufrágio
universal. Mas não soube ainda conquistá-las. Urge que o seu
voto, como sucedeu na Itália e na Alemanha, não seja de tal modo
pervertido, que uma faculdade democrática se converta em arma
antidemocrática. As massas, no Estado jurídico, já têm o poder de
intervir na formação da vontade estatal. Cumpre evitar apenas que
esse poder se demude em poder de destruir o Estado social da
democracia, porque, se assim fora, estariam atraiçoadas, não as
instituições democráticas, senão as mesmas massas, que
haveriam solapado inconscientemente os seus mais caros
interesses, vendo cair das mãos o poder do voto, ou seja, a maior

35 Veja-se que: Devemos começar anotando uma distinção entre democracia e regra de maioria. Democracia quer dizer regra da maioria legítima, o que significa que o mero fator majoritário III não constitui democracia a menos que condições posteriores sejam satisfeitas. É controverso o que essas condições exatamente são. Mas algum tipo de estrutura constitucional que uma maioria não pode mudar é certamente um prérequisito para a democracia. Devem ser estabelecidas normas constitucionais estipulando que uma maioria não pode abolir futuras eleições, por exemplo, ou privar uma minoria dos direitos de voto. (DWORKIN, 1995, p. 2).

36 BONAVIDES, Paulo. Direitos fundamentais, globalização e neoliberalismo. Disponível em: http://www.egov.ufsc.br/portal/sites/default/files/anexos/1499114992-1-PB.pdf Acesso em: 20 maio 2015. p.139-140. 
SILVA, Adamir André. A corrupção como fator impeditivo da democracia: uma leiturada obra Glória Incerta aplicada ao Brasil. Revista Eletrônica Direito e Política, Programa de PósGraduação Stricto Sensu em Ciência Jurídica da UNIVALI, Itajaí, v.11, n.2, 20 quadrimestre de 2016. Disponível em: www.univali.br/direitoepolitica - ISSN 1980-7791.

arma de libertação política e social que o homem moderno já conheceu. ${ }^{37}$

Salienta Sartori38, que a política está relacionada com subordinação, supra-ordenação e coordenação, em essência, estruturação hierárquica da coletividade, a qual o autor denomina de "dimensão vertical da política". A política também está relacionada a uma "dimensão horizontal", mas essa dimensão só se salienta nas democracias. O único termo que se referia à visão horizontal é respublica, cuja tradução mais próxima em língua inglesa é common weal (bem-estar, felicidade). Todos os demais termos desenvolvidos na idade Média referiam-se a verticalidade da política, até mesmo os termos Estado e soberania. A opinião pública, a democracia eleitoral, a democracia participativa, a democracia de referendo, representam uma implementação e uma difusão horizontal da democracia. E é no (re) estabelecimento disso que reside à singularidade da democracia horizontal. Se a democracia eleitoral engloba tipicamente o plano horizontal da democracia, sua sequência ou completamento é a democracia representativa. A questão que se põe é como a regra da maioria se articula, afinal, com a regra da minoria? De início, só dois pontos estão definidos: onde o processo começa e o que se propõe evitar. Começa com a regra do jogo que estabelece como os conflitos devem ser resolvidos; e a regra (método) é o princípio de maioria. O propósito é evitar dar "todo o poder" a muitos ou a poucos, distribuindo-o em turnos e/ou simultaneamente entre maiorias e minorias.

A opinião pública, a democracia eleitora, a democracia participativa, a democracia de referendo - representam todas uma

37 BONAVIDES, Paulo. Direitos fundamentais, globalização e neoliberalismo. Disponível em: http://www.egov.ufsc.br/portal/sites/default/files/anexos/1499114992-1-PB.pdf Acesso em: 20 maio 2015. p.199-200.

38 SARTORI, Giovani. A teoria da democracia revisitada. Tradução de Dinah de Abreu Azevedo. São Paulo: Ática, 1994. p. 181-183. 
SILVA, Adamir André. A corrupção como fator impeditivo da democracia: uma leiturada obra Glória Incerta aplicada ao Brasil. Revista Eletrônica Direito e Política, Programa de PósGraduação Stricto Sensu em Ciência Jurídica da UNIVALI, Itajaí, v.11, n.2, 2ㅇ quadrimestre de 2016. Disponível em: www.univali.br/direitoepolitica - ISSN 1980-7791.

\begin{abstract}
implementação e uma difusão horizontal da democracia. Esse é um ponto de partida correto, pois a singularidade da democracia reside precisamente em estabelecer, ou restabelecer, a dimensão horizontal da política. No entanto, democracia não é anarquia falta ou ausência de comando. A opinião pública, as eleições, a participação e um demos que decide (de uma forma ou de outra), representam os alicerces de um edifício; mas os alicerces, embora essenciais, são algo que sustentam uma construção que é sobreposta. É hora, portanto de examinar a democracia como um sistema de governo e, mais genericamente, estudar a estruturação vertical da democracia - a democracia vertical, em síntese. Se a democracia eleitoral engloba tipicamente o plano horizontal da democracia, sua sequência ou completamento é a democracia representativa. Mas a estruturação vertical da democracia levanta questões que não podem ser solucionadas pela teoria da representação. A questão espinhosa é: como a regra da maioria se articula, afinal, com a regra da minoria? O mérito da questão (assim formulada) é que nos leva a examinar de perto os termos regra, maioria e minoria. ${ }^{39}$
\end{abstract}

Sartori40 argumenta que basta de "maioria" em seus múltiplos sentidos. Está na hora de enfrentar a "minoria", não apenas e, seus múltiplos sentidos, mas também na série superabundante de suas denominações: classe política, classe governante (dominante), elite (s), elite do poder, elite dirigente, minorias dirigentes, liderança e outras. Quando se analisa político se volta para a democracia vertical, não está interessado em qualquer tipo concebível de minoria substantiva, mas apenas nas minorias que constituem algum tipo de "grupo de controle".

Dessa forma, os critérios para selecionar uma minoria são numerosos. Dentre estes, dois são de enorme importância. O primeiro é o critério "altimétrico", um grupo de controle é um grupo que, na estruturação vertical das sociedades, localiza-se no "topo". O critério altimétrico supõe

39 SARTORI, Giovani. A teoria da democracia revisitada. Tradução de Dinah de Abreu Azevedo. São Paulo: Ática, 1994. p.182.

40 SARTORI, Giovani. A teoria da democracia revisitada. Tradução de Dinah de Abreu Azevedo. São Paulo: Ática, 1994. p. 195-199. 
SILVA, Adamir André. A corrupção como fator impeditivo da democracia: uma leiturada obra Glória Incerta aplicada ao Brasil. Revista Eletrônica Direito e Política, Programa de PósGraduação Stricto Sensu em Ciência Jurídica da UNIVALI, Itajaí, v.11, n.2, 20 quadrimestre de 2016. Disponível em: www.univali.br/direitoepolitica - ISSN 1980-7791.

que quem está no topo "tem poder"; um pressuposto justificado pelo motivo lógico de que o fato de ter poder coloca no topo. Deixando-se a santificação de uma situação de fato: quem está no topo está no topo, e quem está lá é poderoso, exerce e tem poder. O segundo critério é o de mérito, segundo o qual, a organização vertical da sociedade deveria ser confiada a pessoas reconhecidamente eminentes. Assim, alguém não está no topo porque tem poder, mas muito ao contrário, uma pessoa tem poder e está no topo porque o merece. ${ }^{41}$

Bonavides $^{42}$ evidencia que a democracia por direito será, de necessidade, tanto quanto possível, uma democracia direta e participativa. Materialmente efetivada, a partir do progresso da tecnologia de comunicação, e legitimamente sustentável, graças à informação correta e às aberturas pluralistas do sistema, há de ser também democracia isenta já das contaminações da mídia manipuladora, já do hermetismo de exclusão, de índole autocrática e unitarista, familiar aos monopólios do poder. Tudo isso, obviamente, se a informação e o pluralismo vingarem por igual como direitos paralelos e coadjutores da democracia; esta, porém, enquanto direito do gênero humano, projetado e concretizado no derradeiro grau de sua evolução conceitual.

Para Bonavides:

O Brasil é hoje um país constitucional, mas não é um país democrático. Não é democrático País que governa para banqueiros, concentra a renda e perpetua o privilégio, que tem nas cidades uma classe média empobrecida e aviltada, que deixa à fome e ao abandono, sem terra, sem pão, sem emprego, sem teto,

${ }^{41}$ SARTORI, A teoria da democracia revisitada. 1994 p.195-199.

42 BONAVIDES, Paulo. Direitos fundamentais, globalização e neoliberalismo. Disponível em: http://www.egov.ufsc.br/portal/sites/default/files/anexos/1499114992-1-PB.pdf Acesso em: 20 maio 2015. p.7. 
SILVA, Adamir André. A corrupção como fator impeditivo da democracia: uma leiturada obra Glória Incerta aplicada ao Brasil. Revista Eletrônica Direito e Política, Programa de PósGraduação Stricto Sensu em Ciência Jurídica da UNIVALI, Itajaí, v.11, n.2, 20 quadrimestre de 2016. Disponível em: www.univali.br/direitoepolitica - ISSN 1980-7791.

sem saúde, sem hospital e sem escola, milhões de brasileiros, arremessados à penúria e indigência; um país que na falácia social da Abolição, transcorridos mais de cento e dez anos, fez o alforriado de ontem sair das senzalas da escravidão negra para as favelas da escravidão branca.

Portanto, a democracia para ser efetivada precisa de representantes comprometidos com a sociedade, e não com o mercado, tornando-se agentes da corrupção. Contudo, a democracia passa pelo fortalecimento das instituições e não pelo descrédito da ordem política e jurídica, como observa-se atualmente.

\section{PROBlemAS DE CORRUPÇÃO}

Retomando-se o assunto corrupção, calha mencionar que o grande problema da corrupção é exatamente o desvio de recursos público que deveriam ser empregados à sociedade - educação, saúde, segurança, geração de emprego. Essa condição é comum entre Índia e Brasil.

Tão flagrante é essa identificação, que Dréze e $\operatorname{Sen}^{43}$, referem-se aos programas brasileiros para erradicação da pobreza - Bolsa Família - como uma forma de focalização de recursos públicos, que em teoria é perfeito, no entanto, na prática têm seus problemas. Programa que teve uma experiência positiva no Brasil e não na Índia.

E não é somente nesse sentido há identidade, também com relação ao papel da mídia na desigualdade entre os indivíduos. As mídias, indianas e brasileiras, não são livres, uma vez que dominadas por famílias tradicionais que representam a elite, os ricos. Os meios de comunicação são guiados pelo mercado publicitário.

No que se refere as promessas democráticas não cumpridas:

43 DRÈZE, Jean; SEN, Amartya. Glória Incerta: A Índia e suas contradições. Tradução de Ricardo Doninelli Mentes e Laila Coutinho. São Paulo: Companhia das Letras, 2015. p. 214. 
SILVA, Adamir André. A corrupção como fator impeditivo da democracia: uma leiturada obra Glória Incerta aplicada ao Brasil. Revista Eletrônica Direito e Política, Programa de PósGraduação Stricto Sensu em Ciência Jurídica da UNIVALI, Itajaí, v.11, n.2, 20 quadrimestre de 2016. Disponível em: www.univali.br/direitoepolitica - ISSN 1980-7791.

O fracasso em eliminar a acentuada divisão entre os privilegiados e os demais é uma grande parte dessa história. Ao analisar a prática da democracia, temos de perguntar: em que medida a democracia indiana tem sido capaz de enfrentar os desafios que essas falhas representam? O sistema democrático certamente deu ao país enormes oportunidades para enfrentar os insucessos em termos de desenvolvimento, mas suas realizações na eliminação da desigualdade e injustiça, porém, têm sido limitadas. ${ }^{44}$

Facilmente se poderia ocultar a identificação do país a que se está referindo, e tanto poder-se-ia pensar em Brasil quanto na Índia, as mazelas da Democracia têm a mesma descrição.

Índia e Brasil mostram para o mundo somente a face que interessa, e não tratam suas mazelas, as varrem para baixo do tapete.

A Índia que estamos louvando é apenas um microcosmo deste vasto território. É a Índia da elite, dos privilegiados, dos ricos. A única Índia que queremos que o resto do mundo veja e reconheça, porque estamos tremendamente envergonhados da outra. Envergonhados e ignorantes.

Assim é com o Brasil, sobretudo com os recentes eventos: Copa do Mundo, Carnaval, Novelas e a Olimpíada que está por acontecer. Todavia ocultamos cifras da criminalidade, prostituição, favelização etc.

Realmente há que se constatar a similitude entre Índia e Brasil e que parte dessa condição passa pela corrupção que condena os dois países ao enfraquecimento da Democracia quando não consegue proporcionar igualdade entre seus cidadãos.

44 DRÈZE, Jean; SEN, Amartya. Glória Incerta: A Índia e suas contradições. Tradução de Ricardo Doninelli Mentes e Laila Coutinho. São Paulo: Companhia das Letras, 2015. p.278. 
SILVA, Adamir André. A corrupção como fator impeditivo da democracia: uma leiturada obra Glória Incerta aplicada ao Brasil. Revista Eletrônica Direito e Política, Programa de PósGraduação Stricto Sensu em Ciência Jurídica da UNIVALI, Itajaí, v.11, n.2, 2ㅇ quadrimestre de 2016. Disponível em: www.univali.br/direitoepolitica - ISSN 1980-7791.

Abordam-se alguns problemas que advém deste fenômeno - corrupção-, e é procedente inferir que dentre os motivos para a prática da mesma, os mais evidentes são: a econômica, a política e a cultural. As causas econômicas relativas à corrupção "estão associadas principalmente à obtenção de vantagens financeiras ilegais por parte dos agentes envolvidos". ${ }^{45}$ As causas políticas referem-se a busca ou manutenção do poder e da melhor acomodação política. Enquanto que as causas culturais se vinculam "crenças, ideologias, religião ou comportamento social que contribuem para a existência de uma tolerância com a corrupção". Entretanto, independente da categoria da causa, seus efeitos e problemas, além de correlacionados a atitude humana, interferem no estabelecimento de ações que venham beneficiar a maioria em todas as esferas, econômica, social e política. ${ }^{46}$

No setor privado, de acordo com Aldrighi, a corrupção assume um caráter preocupante:

Conflitos de interesse e abuso do poder confiado para a obtenção de ganhos privados podem assumir várias formas dentro de uma empresa. Os casos aqui descritos são apenas algumas ilustrações do problema. Diversos outros tipos de fraude empresarial têm sido identificados e amplamente documentados. Fusões e aquisições de empresas fornecem elevadas oportunidades para que pessoas com informações privilegiadas as utilizem para lucrar às custas de outros investidores. Há evidências de que executivos de bancos de investimento compram ações em quantidades e frequência incomuns de empresas que são alvos de fusões enquanto seus colegas assessoram a ponta compradora do negócio, levantando a forte suspeita de fluxos incontidos e ilegais de informações privilegiadas. Da mesma forma, sérios conflitos de interesse podem ocorrer quando empresas de private equity compram

\footnotetext{
45 ZANINI, Juliano Cesar. Corrupção administrativa e mecanismos de controle externo: discussão doutrinária principiológica. Dissertação (Mestrado em Ciência Jurídica) Universidade Vale do Itajaí. Itajaí - SC, 2014. p.30.

${ }^{45}$ ZANINI, Corrupção administrativa e mecanismos de controle externo: discussão doutrinária principiológica. 2014, p.30.
} 
SILVA, Adamir André. A corrupção como fator impeditivo da democracia: uma leiturada obra Glória Incerta aplicada ao Brasil. Revista Eletrônica Direito e Política, Programa de PósGraduação Stricto Sensu em Ciência Jurídica da UNIVALI, Itajaí, v.11, n.2, 2ㅇ quadrimestre de 2016. Disponível em: www.univali.br/direitoepolitica - ISSN 1980-7791.

empresas listadas em bolsa e negociam os termos da operação com os mesmos executivos que se tornarão seus subordinados após a tomada do controle acionário. Não se pode subestimar a escala e o escopo dos riscos de corrupção empresarial interna, embora estatísticas concretas sejam somente aproximações, uma vez que muitos casos podem não ser publicamente divulgados. ${ }^{47}$

A corrupção no setor privado tem impactos negativos amplos, podendo abranger inúmeras instituições, como políticos, sindicatos, empresas, clientes, fornecedores enfim tornar-se uma pandemia.

Acrescenta Hess ${ }^{48}$ dentre as muitas faces da corrupção no setor privado, esta pode concretizar-se na aquisição de insumos, passando pelas operações internas de criação de valor, até a venda final e a distribuição ao consumidor, etapa denominada de cadeia de valor.

Portanto, é possível mencionar que a corrupção se tornou um problema mundial, no Brasil percebe-se iniciativas para obstaculizar essa prática. Nesse sentido, a Controladoria-Geral da União considera:

A corrupção é um problema que atinge a todos os Estados Nacionais, a todas as comunidades e a cada indivíduo. É um fenômeno cultural que se estrutura a partir de distorções nas relações econômicas, sociais e políticas entre países, instituições e pessoas. Resulta, fundamentalmente, da distribuição desigual de renda, das fragilidades organizacionais das instituições, do excesso da burocracia, da deficiência na governança e da baixa legitimação das representações políticas, das desigualdades de oportunidades políticas, econômicas e sociais, entre outras. Diante disso, o Estado Brasileiro vem ampliando e fortalecendo suas políticas de prevenção e combate à corrupção. Diversas dessas políticas vêm sendo desenvolvidas por meio da Controladoria-Geral da União (CGU), que, criada pela Lei n. ${ }^{\circ} 10.683$, de 28 de maio de 2003,

47 ALDRIGHI, Dante Mendes. Corrupção nas empresas: fraudes e conflitos de interesse. Relatório Global de Corrupção: corrupção e o setor privado. Cambridge University Press: Transparency International, 2009. p.15.

48 HESS, David. Corrupção na cadeia de valor: no setor privado e entre os setores público e privado. Relatório Global de Corrupção: corrupção e o setor privado. Cambridge University Press: Transparency International, 2009. p.17. 
SILVA, Adamir André. A corrupção como fator impeditivo da democracia: uma leiturada obra Glória Incerta aplicada ao Brasil. Revista Eletrônica Direito e Política, Programa de PósGraduação Stricto Sensu em Ciência Jurídica da UNIVALI, Itajaí, v.11, n.2, 2ㅇ quadrimestre de 2016. Disponível em: www.univali.br/direitoepolitica - ISSN 1980-7791.

atua como órgão central das funções de controle interno, correição e ouvidoria no Poder Executivo do Governo Federal Brasileiro. A Controladoria-Geral da União - CGU desenvolve, nesse sentido, ações voltadas para a promoção da transparência e para a prevenção da corrupção. Competem à CGU a defesa do patrimônio público e o incremento da transparência da gestão, além da supervisão técnica dos órgãos que compõem o Sistema de Controle Interno do Poder Executivo Federal. A orientação e a metodologia de trabalho empregadas pela Controladoria-Geral da União buscam promover, de um lado, a integração efetiva das ações de fiscalização, auditoria e correição e, de outro, a articulação entre essas ações da CGU e as dos demais órgãos públicos que desenvolvem ações similares ou complementares, a exemplo do Ministério Público Federal e dos Estados, da Advocacia-Geral da União, do Tribunal de Contas da União, do Ministério da Justiça, da Polícia Federal, Receita Federal e do Conselho de Controle de Atividades Financeiras. ${ }^{49}$

Acerta Cartier-Bresson ${ }^{50}$ quando diz que as discussões em relação à corrupção não se limita ao Estado e sua obrigação de coibir e punir, mas a questão da natureza e da forma concreta das intervenções estatais necessárias. A desconfiança em face das novas maneiras de enriquecimento e a falta de confiança na classe política nos países que adotaram políticas de ajuste estrutural e democratização conferem atualidade à pesquisa sobre as formas correntes de corrupção nos países em desenvolvimento.

Para o autor:

Os comportamentos arbitrários e a fraca legitimidade de certos Estados, que não protegem os agentes econômicos nem cuidam de

49 BRASIL. Ministério do Planejamento, Orçamento e Gestão. Secretaria de Gestão. Comissão Européia. Seminário Brasil-Europa de prevenção da corrupção: textos de referência / Ministério do Planejamento, Orçamento e Gestão. Secretaria de Gestão - Brasília: MP, 2007. p.9.

50 CARTIER-BRESSON, Jean. Corrupções, liberalizações e democratizações. In: BRASIL. Ministério do Planejamento, Orçamento e Gestão. Secretaria de Gestão. Comissão Européia. Seminário Brasil-Europa de prevenção da corrupção: textos de referência / Ministério do Planejamento, Orçamento e Gestão. Secretaria de Gestão Brasília: MP, 2007. p.50. 
SILVA, Adamir André. A corrupção como fator impeditivo da democracia: uma leiturada obra Glória Incerta aplicada ao Brasil. Revista Eletrônica Direito e Política, Programa de PósGraduação Stricto Sensu em Ciência Jurídica da UNIVALI, Itajaí, v.11, n.2, 2ㅇ quadrimestre de 2016. Disponível em: www.univali.br/direitoepolitica - ISSN 1980-7791.

\begin{abstract}
organizar as negociações entre eles, dão margem a que surjam sistemas alternativos de proteção ou ajuda mútua baseados em micro-legitimações tais como a família, o clã, a etnia, a região, a facção do crime, o grupo de guerrilha, etc. Esses sistemas em rede, dada a sua natureza, excluem todos os que não se submetam ao esquema local voluntariamente (ética) ou por incapacidade (nenhum recurso a oferecer). O sentimento de distribuição inicial injusta dos direitos privados e públicos de propriedade (ou de um acesso fechado que acentua a marginalização) ou de alocação de novos direitos para favorecer o surgimento de uma elite põe em questão as normas de justiça. Se a distribuição legal de favores a certas partes da elite não beneficiar indiretamente a população como um todo, graças a mecanismos de geração ou redistribuição de renda, é grande o risco de que ocorra uma considerável queda na lealdade dos atores em relação às normas do poder público. ${ }^{51}$
\end{abstract}

Vincula-se ao assunto corrupção a questão da eficiência e das estratégias de desenvolvimento, as quais necessitam estar na pauta das preocupações dos países que são afetados e sentem que seu desenvolvimento se encontra estagnado, e suas carências aumentam diariamente devido a corrupção.

O tema é de extrema relevância que se tornou pauta na Convenção das Nações Unidas em 2003, da qual o Brasil tornou-se signatário em 09 de dezembro de 2003 por meio do Decreto $n^{\circ} 5.687$, de 31 de janeiro de 2006. Considerada como o maior e mais completo instrumento global e juridicamente vinculante contra a corrupção, a Convenção das Nações Unidas contra a Corrupção tratou de diversos aspectos, tendo sido fundamentada em quatro tópicos especiais: a) medidas preventivas; b) criminalização e aplicação da lei; c) cooperação internacional; e, d) recuperação de ativos. 52

51 CARTIER-BRESSON, Jean. Corrupções, liberalizações e democratizações. In: BRASIL. Ministério do Planejamento, Orçamento e Gestão. Secretaria de Gestão. Comissão Européia. Seminário Brasil-Europa de prevenção da corrupção: textos de referência / Ministério do Planejamento, Orçamento e Gestão. Secretaria de Gestão Brasília: MP, 2007. p.24. 
SILVA, Adamir André. A corrupção como fator impeditivo da democracia: uma leiturada obra Glória Incerta aplicada ao Brasil. Revista Eletrônica Direito e Política, Programa de PósGraduação Stricto Sensu em Ciência Jurídica da UNIVALI, Itajaí, v.11, n.2, 2ㅇ quadrimestre de 2016. Disponível em: www.univali.br/direitoepolitica - ISSN 1980-7791.

Calha recordar que Índia e Brasil são Estados membros-fundadores da ONU por terem assinado a Declaração das Nações Unidas em $1^{0}$ de janeiro de 1942, ou por tomarem parte da Conferência de São Francisco de 1945 e terem ratificado a mesma.

Nesta seara, de análise da corrupção, necessário se faz, mencionar a importância do tema, bem como as medidas de prevenção e sua eficácia.

Os casos revelados pela imprensa provocam escândalo e indignação na sociedade, sendo estes fatos recorrentes. Porém, apesar de numerosas tentativas para erradicar esse fenômeno, a corrupção continua numa escala planetária. Os problemas e as consequências da corrupção tornamse também obstáculo ao desenvolvimento humano das sociedades modernas. Nesse sentido, o Relatório de Desenvolvimento Humano afirma:

A corrupção e instituições públicas sem capacidade de resposta podem privar aqueles que carecem de ajuda, dos necessários recursos. As ameaças de índole política, as tensões entre comunidades, os conflitos violentos, a negligência perante a saúde pública, os danos ambientais, a criminalidade e a discriminação constituem, todos eles, fatores de agravamento da vulnerabilidade dos indivíduos e das comunidades. Conseguir um progresso real em matéria de desenvolvimento humano não passa, assim, unicamente por ampliar o leque de opções de escolha determinantes das pessoas e a sua capacidade de acederem à educação e à saúde e de desfrutarem de um nível de vida razoável e de uma sensação de segurança. Depende também do grau de

52 MEDIDAS PREVENTIVAS: Do artigo $5^{\circ}$ ao artigo 14, são os seguintes os temas versados pela Convenção: I - Políticas e práticas de prevenção da corrupção; II - Órgão ou órgãos de prevenção da corrupção; III - Medidas de prevenção da corrupção para gestão no setor público; IV - Códigos de conduta para funcionários públicos; V Contratação pública e gestão da fazenda pública; VI - Medidas para promoção da transparência pública; VII - Medidas para assegurar a independência do Poder Judiciário e do Ministério Público; VIII - Medidas de prevenção da corrupção no setor privado; IX - Fomento da participação da sociedade; X - Medidas para prevenir a lavagem de dinheiro. (CONVENÇÃO DAS NAÇÕES UNIDAS, 2008, p. 8) 
SILVA, Adamir André. A corrupção como fator impeditivo da democracia: uma leiturada obra Glória Incerta aplicada ao Brasil. Revista Eletrônica Direito e Política, Programa de PósGraduação Stricto Sensu em Ciência Jurídica da UNIVALI, Itajaí, v.11, n.2, 2ㅇ quadrimestre de 2016. Disponível em: www.univali.br/direitoepolitica - ISSN 1980-7791.

solidez dessas conquistas e da existência de condições suficientes para um desenvolvimento humano sustentado. ${ }^{53}$

Contudo, na contemporaneidade a democracia efetiva, ainda é um desafio, para enfrentá-lo, tem-se que fazer uma opção transparente e substancial pelo combate sistematizado à corrupção ${ }^{54}$. Dessa forma, reduzir índices de corrupção significa ganhos em desenvolvimento humano, governos eficazes viabilizadores de serviços de qualidade e compromissados com o Estado Democrático de Direito.

A democracia se fragiliza com a corrupção,

Desta forma, a república democrática é corrompida quando as virtudes cívicas dão lugar aos interesses privado, cuja igualdade leva ao espírito de igualdade extrema, em que cada cidadão não mais quer obedecer à autoridade legítima do Estado, mas às suas próprias convicções, resultando na desordem total. O efeito da corrupção da democracia é sua condução ao despotismo de um só em decorrência do espírito de igualdade extrema. O não devotamento à coletividade conduz à licenciosidade e à libertinagem, redundando na supremacia dos interesses privados sobre os interesses público. Na medida em que a república não precisa de leis positivas, ela facilmente se corrompe, dado que seu princípio organizador é a virtude. ${ }^{55}$

Portanto, os problemas que se apresentam em razão do aumento da corrupção, relacionam-se a manutenção do poder em detrimento da sociedade, comprometimento das esferas pública e privada, com seus interesses dicotômicos, exigindo transparência e ética, para que se possa de fato efetivar a democracia.

53 Relatório do Desenvolvimento humANO. PNUD: Camões - Instituto da Cooperação e da Língua, 2014. p.1.

54 STAFFEN, Márcio Ricardo; OLIVIERO, Maurizio. A transparência enquanto pretensão jurídica global. A\&C - Revista de Direito Administrativo \& Constitucional, Belo Horizonte, v. 15, n. 61, p. 61-71, jul.-set. 2015.

55 AVRITZER, Leonardo; FILGUEIRAS, Fernando. Corrupção e sistema político no Brasil. Rio de Janeiro: Civilização Brasileira, 2011. p. 20. 

Glória Incerta aplicada ao Brasil. Revista Eletrônica Direito e Política, Programa de PósGraduação Stricto Sensu em Ciência Jurídica da UNIVALI, Itajaí, v.11, n.2, 2o quadrimestre de 2016. Disponível em: www.univali.br/direitoepolitica - ISSN 1980-7791.

\section{CONSIDERAÇÕES FINAIS}

Pretendeu-se revisitar a obra Glória Incerta, traçando um ponto de contato entre os problemas vivenciados na Índia e no Brasil no que concerne a corrupção como fator impeditivo da democracia, verificou-se que, trata-se de realidades semelhantes, com as mesmas causas, consequências e que pode ser utilizado o mesmo tratamento a fim de erradicá-la nos dois Estados.

É visível em ambos - Índia e Brasil, questões que podem configurar um impeditivo a democracia, principalmente ao refletir sobre igualdade de direitos, política e economia. Necessário pois, adoção de uma política efetiva de transparência das contas públicas, accountability, instituições fortes, mídia livre e independente, e a participação da sociedade civil organizada. Este conjunto de medidas podem erradicar a corrupção.

Por outro lado, o investimento em educação formará cidadãos com senso de ética e moral que não aceitam práticas ilegais, também o reconhecimento do "eu no outro", propiciará um ambiente favorável à igualdade entre os indivíduos.

Portanto, democracia e sustentabilidade abrangem oportunidades iguais em relação às necessidades da sociedade vinculadas ao bem estar e ao desenvolvimento social, indo além de conquistas de liberdade e direito ao voto, pois é preciso ter-se o domínio da informação e conhecimento para exercer a cidadania.

A corrupção pode manipular a livre expressão e essa possibilidade já reduz as chances de fortalecimento da democracia, torna o combate à corrupção mais difícil, ao confundir a sociedade, através dos meios de 
SILVA, Adamir André. A corrupção como fator impeditivo da democracia: uma leiturada obra Glória Incerta aplicada ao Brasil. Revista Eletrônica Direito e Política, Programa de PósGraduação Stricto Sensu em Ciência Jurídica da UNIVALI, Itajaí, v.11, n.2, 20 quadrimestre de 2016. Disponível em: www.univali.br/direitoepolitica - ISSN 1980-7791.

comunicação, que tendenciosos, interferem negativamente no processo democrático.

No que se refere ao Brasil, temos que esse contexto colabora para que a reforma política seja atualmente um dos temas mais debatidos no Brasil, exigindo que a sociedade brasileira reconheça a importância de se tornar protagonista de sua história, buscando efetivar seus direitos por meio de uma abertura que the proporcione modificar a forma de entender e fazer política no Brasil.

Daí falar-se em manifestações populares, comprometimento ético e transparente em todas as esferas, sejam institucionais, econômicas, sociais, públicas ou privadas.

Comprometimento que é garantia insculpida no parágrafo único do artigo primeiro da Constituição Federal de 1988, ao dispor: "o poder emana do povo". Desta forma, a corrupção deve ser analisada em termos civis, criminais e éticos, para que não seja criada uma cultura de regra e que o poder da sociedade possa realmente interferir, ao ponto de erradicar a cultura da corrupção.

Uma postura consciente, responsável e ativa pode determinar que os eleitos pela população, os políticos, os detentores de cargos públicos mudem a própria concepção exercício da função, visando, a partir dessa nova concepção, os interesses da sociedade.

Ponderando-se, então, em que medida a corrupção e/ou aumento da corrupção é um fator impeditivo da democracia de um Estado Democrático de Direito, conclui-se que de fato, vultosas somas em dinheiro, necessárias e capazes para a erradicação da pobreza, saúde, educação, 

Glória Incerta aplicada ao Brasil. Revista Eletrônica Direito e Política, Programa de PósGraduação Stricto Sensu em Ciência Jurídica da UNIVALI, Itajaí, v.11, n.2, 20 quadrimestre de 2016. Disponível em: www.univali.br/direitoepolitica - ISSN 1980-7791.

segurança pública, programas sociais, são drenados pela via inescrupulosa, silenciosa e obscura da corrupção.

Todavia, instrumentos aptos à mudança encontram-se à disposição. Resta a mudança de atitude e conscientização, para tornarem-se, a exemplo da Suécia, Irlanda e Holanda, livres da corrupção, alcançando assim a concretização de uma Democracia plena num Estado Democrático de Direito.

\section{REFERÊNCIAS DAS FONTES CITADAS}

ALDRIGHI, Dante Mendes. Corrupção nas empresas: fraudes e conflitos de interesse. Relatório Global de Corrupção: corrupção e o setor privado. Cambridge University Press: Transparency International, 2009.

ARENDT, Hannah. Crises da República. Tradução: José Volkmann, São Paulo: Perspectiva, 2015.

AVRITZER, Leonardo; FILGUEIRAS, Fernando. Corrupção e sistema político no Brasil. Rio de Janeiro: Civilização Brasileira, 2011.

BOBBIO, Norberto. O futuro da democracia: uma defesa das regras do jogo. Tradução de Marco Aurélio Nogueira. Rio de Janeiro: Paz e Terra, 1986.

BRASIL. Constituição da República do Brasil: promulgada em 5 de outubro de 1988. São Paulo: Saraiva, 2015.

. Norberto. O futuro da democracia. Tradução de Marco Aurélio Nogueira. São Paulo: Paz e Terra, 2000.

Norberto; MATTEUCCI, Nicola; PASQUINO, Gianfranco. Dicionário de Política. 5. ed. Brasília: UNB, 2000.

BONAVIDES, Paulo. Direitos fundamentais, globalização e neoliberalismo. Disponível em: http://www.egov.ufsc.br/portal/sites/default/files/anexos/14991-149921-PB.pdf Acesso em: 20 maio 2015. 

Glória Incerta aplicada ao Brasil. Revista Eletrônica Direito e Política, Programa de PósGraduação Stricto Sensu em Ciência Jurídica da UNIVALI, Itajaí, v.11, n.2, 20 quadrimestre de 2016. Disponível em: www.univali.br/direitoepolitica - ISSN 1980-7791.

2013.

. Paulo. Do Estado Liberal ao Estado Social. 11. ed. São Paulo,

BRASIL. Ministério do Planejamento, Orçamento e Gestão. Secretaria de Gestão. Comissão Européia. Seminário Brasil-Europa de prevenção da corrupção: textos de referência / Ministério do Planejamento, Orçamento e Gestão. Secretaria de Gestão - Brasília: MP, 2007.

BRAUN, Michele. O fenômeno corrupção: de suas raízes a revitalização da cidadania como forma de enfrentamento do vício social. In: LEAL, Rogerio Gesta; SILVA, Ianaiê Simonelli. (Orgs.). As múltiplas faces da corrupção e seus efeitos na democracia contemporânea [recurso eletrônico]. Santa Cruz do Sul: EDUNISC, 2014.

CARTIER-BRESSON, Jean. Corrupções, liberalizações e democratizações. In: BRASIL. Ministério do Planejamento, Orçamento e Gestão. Secretaria de Gestão. Comissão Européia. Seminário Brasil-Europa de prevenção da corrupção: textos de referência / Ministério do Planejamento, Orçamento e Gestão. Secretaria de Gestão - Brasília: MP, 2007.

. Jean. Da velha à nova corrupção nos países em desenvolvimento. In: BRASIL. Ministério do Planejamento, Orçamento e Gestão. Secretaria de Gestão. Comissão Européia. Seminário Brasil-Europa de prevenção da corrupção: textos de referência / Ministério do Planejamento, Orçamento e Gestão. Secretaria de Gestão - Brasília: MP, 2007.

CONVENÇÃO DAS NAÇÕES UNIDAS CONTRA A CORRUPÇÃO - Presidência, Controladoria-Geral da União. Brasília: CGU, 2008.

DRÈZE. Jean; SEN, Amartya. Glória Incerta: A Índia e suas contradições. Tradução de Ricardo Doninelli Mentes e Laila Coutinho. São Paulo: Companhia das Letras, 2015.

DWORKIN, Ronald. Constitucionalismo e Democracia. Traduzido de Emílio Peluso Neder Meyer. European Journal of Philosophy, v. 1, n. 3, p. 2$11,1995$.

FRATTON, Elisangela Furian. A dignidade da pessoa humana e o fenômeno da corrupção no Brasil. In: LEAL, Rogerio Gesta; SILVA, Ianaiê Simonelli. (Orgs.). As múltiplas faces da corrupção e seus efeitos na democracia contemporânea [recurso eletrônico]. Santa Cruz do Sul: EDUNISC, 2014.

GRUBBA, Leilane Serratine. Entre quatro paredes: clausura do ser-político em uma sociedade democrática. In: Simpósio de Direito e Literatura (1: 

Glória Incerta aplicada ao Brasil. Revista Eletrônica Direito e Política, Programa de PósGraduação Stricto Sensu em Ciência Jurídica da UNIVALI, Itajaí, v.11, n.2, 20 quadrimestre de 2016. Disponível em: www.univali.br/direitoepolitica - ISSN 1980-7791.

2010: Florianópolis, SC) Anais [do] I Simpósio de Direito e Literatura; Luis Carlos Cancellier de Olivo. (Orgs.). Florianópolis: Fundação Boiteux, 2011.

HABERMAS, Jürgen. Direito e democracia: entre facticidade e validade. Tradução de Flávio Beno Siebeneichler. Rio de Janeiro: Tempo Brasileiro, 2003.

HESS, David. Corrupção na cadeia de valor: no setor privado e entre os setores público e privado. Relatório Global de Corrupção: corrupção e o setor privado. Cambridge University Press: Transparency International, 2009.

LEAL, Rogerio Gesta. Os efeitos deletérios da corrupção em face dos direitos humanos e fundamentais. In: LEAL, Rogerio Gesta; SILVA, Ianaiê Simonelli. (Orgs.). As múltiplas faces da corrupção e seus efeitos na democracia contemporânea [recurso eletrônico]. Santa Cruz do Sul: EDUNISC, 2014.

MAZZARDO, Luciane; COSTA, Marli da. Perscrutando os efeitos da corrupção na realidade pátria: a (des) conexão com os direitos sociais. In: LEAL, Rogerio Gesta; SILVA, Ianaiê Simonelli. (Orgs.). As múltiplas faces da corrupção e seus efeitos na democracia contemporânea [recurso eletrônico]. Santa Cruz do Sul: EDUNISC, 2014.

MORAES, Thiago Perez Bernardes de; SANTOS, Romer Motttinha; TORRECILLAS, Geraldo Leopoldo da Silva. Qualidade democrática, percepção de corrupção e confiança política na América Latina. Revista Eletrônica de Ciência Política, v. 5, n. 1, 2014.

PLATÃo, A República. Tradução de Ciro Mioranza. São Paulo: Escala, 2000.

RAWLS, John. O liberalismo político. Tradução de Dinah de Abreu Azevedo. Fenando Paixão (Ed.). São Paulo, 1993.

RELATÓRIO dO DESENVOLVIMENTO HUMANO. PNUD: Camões Instituto da Cooperação e da Língua, 2014.

SANTOS, Kátia P.; AMANAJÁS, Alley Felipe. Democracia e corrupção no Brasil: a face tirana do poder político. Estação Científica (UNIFAP), Macapá, v. 2, n. 1, p. 11-24, jan./jun., 2012.

SARTORI, Giovani. A teoria da democracia revisitada. Tradução de Dinah de Abreu Azevedo. São Paulo: Ática, 1994. 
SILVA, Adamir André. A corrupção como fator impeditivo da democracia: uma leiturada obra Glória Incerta aplicada ao Brasil. Revista Eletrônica Direito e Política, Programa de PósGraduação Stricto Sensu em Ciência Jurídica da UNIVALI, Itajaí, v.11, n.2, 2ㅇ quadrimestre de 2016. Disponível em: www.univali.br/direitoepolitica - ISSN 1980-7791.

STAFFEN, Márcio Ricardo; OLIVIERO, Maurizio. A transparência enquanto pretensão jurídica global. A\&C - Revista de Direito Administrativo \& Constitucional, Belo Horizonte, v. 15, n. 61, p. 61-71, jul.-set. 2015.

TOCQUEVILLE, A. de. A democracia na América. Tradução de Neil Ribeiro da Silva. São Paulo: Folha de S. Paulo, 2010.

ZAMBAN, Neuro José. Introdução à Teoria da Justiça de John Rawls. Rio de Janeiro: Lumen Juris, 2015.

ZANINI, Juliano Cesar. Corrupção administrativa e mecanismos de controle externo: discussão doutrinária principiológica. 2014. Dissertação (Mestrado em Ciência Jurídica) Universidade Vale do Itajaí. Itajaí - SC, 2014.

Submetido em: Maio de 2016.

Aprovado em: Julho de 2016. 